\title{
SCIDiC
}

\author{
International Journal of Dentistry and Oral Science (IJDOS) \\ ISSN: 2377-8075
}

\section{Prevalence Of Vertical Maxillary Excess - An Institution Based Retrospective Study}

Research Article

J.Chandra Pooja ${ }^{1}$, Naveen Kumar $^{2 *}$, Ganesh Jeevanandan ${ }^{3}$

${ }^{1}$ Saveetha Dental College and Hospitals, Saveetha Institute of Medical and Technical Sciences, Chennai - 600 077, TN, India.

${ }^{2}$ Reader, Department of Pedodontics, Saveetha Institute of Medical and Technical Sciences, Saveetha University, 162, Chennai - 600077, Tamil Nadu, India.

${ }^{3}$ Senior Lecturer, Department Of Orthodontics and Dentofacial Orthopaedics, Saveetha Dental College and Hospitals, Saveetha Institute of Medical and Technical Sciences (SIMATS) Saveetha University, Chennai, India.

\section{Abstract}

Vertical maxillary excess is a facial deformity with increased anterior total facial height and has a multivariate etiology. Timely diagnosis of the etiology and its treatment can allow normal growth to continue in children. The knowledge of prevalence of vertical maxillary excess provides the clinician a helpful tool to handle such patients in their clinic with clarity and ease.The aim of the study is to evaluate prevalence of maxillary excess in south indian Population.A retrospective study was carried out using case records of 667 patients who reported to the Department of Orthodontics from June 2019 to March 2020.The prevalence of vertical maxillary excess among gender and age group were observed from the digital records and tabulated on a spreadsheet. The collected data was analysed by computer software SPSS version 21 using Chi square test with the level of significance with age and gender. The prevalence of vertical maxillary excess was statically significant with both age $(\mathrm{p}$ value- 0.001$)$ and gender $(\mathrm{p}$ value-0.033). The vertical maxillary excess was most prevalent among the female patients(54.39\%) and among the age group of below 30 years $(67.84 \%)$.

Keywords: Skeletal; Maxilla; Vertical Maxillary Excess.

\section{Introduction}

Facial growth has been studied for many years in the field of orthodontics and it has been established that a definitive relationship exists between growth of cranio-facial structures and dental occlusion [1-4].

Vertical maxillary excess is a facial deformity with increased anterior total facial height due to vertical excess of lower facial third. Individuals may present with different degrees of severity in vertical excess. Vertical maxillary excess may exist alone or in combination with horizontal mandibular deficiency with or without an anterior open bite. The facial contour is characterized by a long, tapering face with anterior and posterior maxillary overgrowth, a narrow alar nose and lip in amptence [5].

Other clinical features include increased lower facial height, an- terior open bite and narrow palate. While excessive vertical facial growth can often be recognized clinically, several cephalometric traits are commonly used to classify the underlying vertical skeletal pattern as normal [normal divergent], short[hypodivergent] or long[hyper divergent].Both genetic and environmental factor have been associated with the etiology of excessive vertical facial development, although it is likely that more than one subtype exists $[6,7]$.

Two of the largest studies that investigated the prevalence of skeletal facial types were undertaken in US and involved the evaluation of large orthodontic based sample size [8]. In both studies the prevalence of long face pattern was approximately $22 \%$ [8] similar studies which have been carried over in South Indian population $[9,10]$.

Black individuals had greater prevalence of long face patterns,

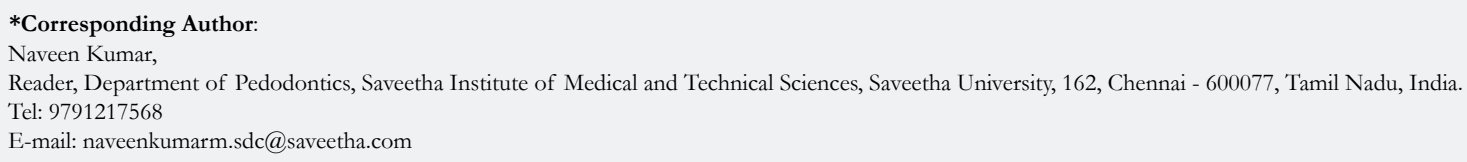

Copyright: Naveen Kumar ${ }^{\circ}$ 2021. This is an open-access article distributed under the terms of the Creative Commons Attribution License, which permits unrestricted use, distribution and reproduction in any medium, provided the original author and source are credited. 
followed by brown white and yellow individuals. Only a small percentage of individuals $[<1 \%]$ presented serve subtype in all the ethic groups. The prevalence of long face pattern was $14.06 \%$ in the population in which $13.39 \%$ and $0.68 \%$ belonged to moderate and severe subtypes respectively [11].

The prevalence of vertical maxillary excess was approximately $22 \%$. This extreme form of vertical craniofacial growth was also reported to be the second common cause of seeking and receiving orthodontic/surgical treatment [8]. Prevalence of these vertical growth patterns differed significantly according to Angle's classification of malocclusion with the highest proportion occurring in class III sample[35\%] followed by class I [32\%] and class II division I[30\%] and division 2 [18\%] groups [12]. The aim of the study is to evaluate the prevalence of dental maxillary excess among men and women and different age groups in the south indian population.

Orthosurgical correction of dentofacial deformities aims to obtain more harmonious and esthetically pleasing facial proportions in addition to normal and stable functional occlusion.The management of vertical maxillary excess includes lefort surgery combined with orthodontist treatment [13-17]. Temporary anchorage devices (TADs) have been shown to be effective in the treatment of VME and/or bimaxillary protrusion [18-21]. Previously our team has a rich experience in working on various research projects across multiple disciplines [22-35]. The aim is to evaluate the vertical maxillary excess in the southindian population.

\section{Materials And Method}

\section{Study design}

In this retrospective study, data from patients records within the institution were revised and the data of patients who had vertical maxillary excess were collected. At data extraction,all information was anonymized and tabulated onto a spreadsheet. The study was commenced after approval from the Institutional Review Board. Patients who had vertical maxillary excess were reviewed to check the prevalence among gender and age.

\section{Subjects and procedures}

Data were collected from June 2019 to March 2020 for 667 pa- tients who had vertical maxillary excess. The following data were retrieved from the dental records: patient age and gender.

\section{Statistical Analysis}

The statistical analysis was done using SPSS software version 21.0 (SPSS Inc., Chicago, IL, USA). The data was verified by the institutional ethical committee and by 2 examiners. All retrospective studies arising from the Data set between 01 June 2019 and 31 march 2020 will be covered by the following ethical approval number. SDC/SIHEC/2020/DIASDATA/0619-0320. The dependent variables were age and gender and independent variables were the patient's willingness, socio economic status.Chi-square test was used to compare the study subject with age and gender.

\section{Result And Discussion}

A total of 667 patients with age from 4 years to 64 years were included in the present study. Chi-square test was done between prevalence of vertical maxillary excess with age and gender.

The results of the study is similar to study by Tjan AH et al which states that the prevalence of vertical maxillary excess is $10 \%$ among the population aged between 20 and 30 years [36].

The results were similar to a study buty Tjan $\mathrm{AH}$ which stated that a study done on 450 individuals with an age range of 20-30 years shows that $7 \%$ of men and $14 \%$ of women were found to have gummy smiles [22].

The study results were also similar to a study done in Brazilian patients with dentofacial deformities whose status among all the deformated VME was present in 33 patients and the prevalence of skeletal deformities was higher in women [23]. Our institution is passionate about high quality evidence based research and has excelled in various fields [37-47].

The limitation of the study in small sample size, very less clinical factors being included and the variation in the results with change in geographical location. The future scope of the study should include different geographical location, study on larger populations with many clinical factors.

Figure 1. Bar chart depicting association between age of patients with prevalence of vertical maxillary excess. The age of the patients were categorised into three groups namely group $1(<30$ years), group 2(31-50 years), group 3( $>50$ years). $\mathrm{X}$ axis represents age of patients and $\mathrm{Y}$ axis represents frequency of patients with different age groups.Prevalence of other skeletal malocclusion greater than the VME.This relation was statistically significant, with Pearson's chi square test $p$ value0.001 .

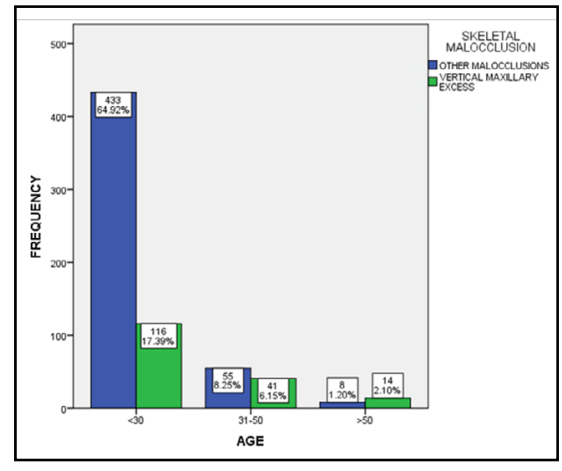


Figure 2. Bar chart depicts the association between gender of patients with prevalence of vertical maxillary excess. $\mathrm{X}$ axis represents gender of patients and $\mathrm{Y}$ axis represents the frequency of patients with different gender groups.Prevalence of other Skeletal malocclusion greater than VME in both gender. This relation was statistically significant, with Pearson's chi square test $\mathrm{p}$ value- $\mathbf{0 . 0 3 3}$.

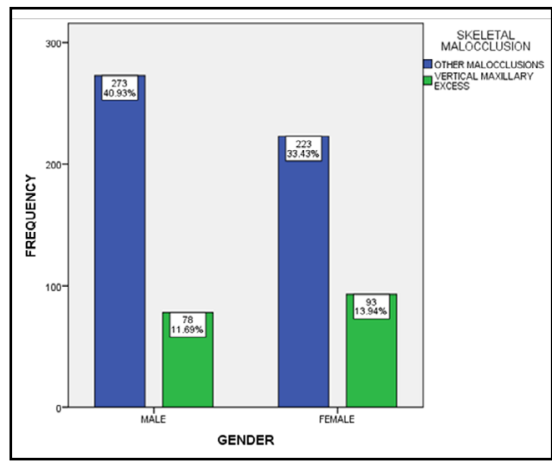

Figure 3. Bar chart depicts the distribution of patients with vertical maxillary excess among different age groups. $\mathrm{X}$ axis represents age of patients and $\mathrm{Y}$ axis represents the frequency of patients with different age groups. Blue colour represents patients of age group below 30 years, red colour represents patients between 31-50 years and green colour patients above 50 years of age. The study results show that vertical maxillary excess is more prevalent among patients under 30 years.

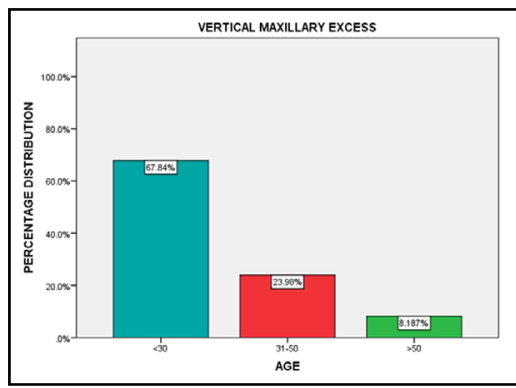

Figure 4. Bar chart depicts the distribution of patients with vertical maxillary excess among gender. $\mathrm{X}$ axis represents gender of patients and $Y$ axis represents the frequency of patients with gender.Dark blue colour represents male patients and pink colour represents female patients. The study results show that vertical maxillary excess is more prevalent in the female population.

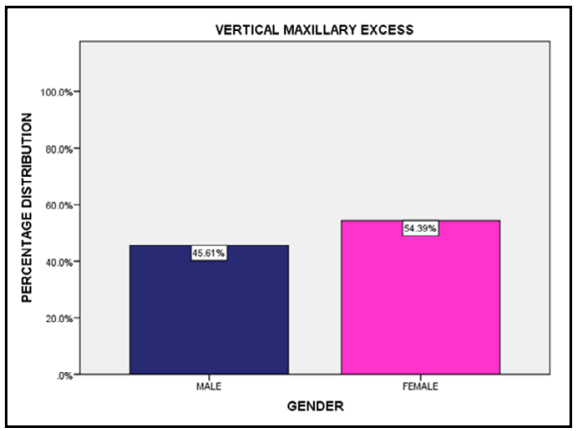

\section{Conclusion}

Within the limitation of the study it can be concluded that prevalence of vertical maxillary excess had significant association with age and gender and it is more prevalent in the female population and in the younger age group of below 30 years. When compared with other skeletal malocclusion VME is lesser in the younger age group.This was due to the change in the pattern of growth in the past 40-50 years that malocclusion is seen more often in the younger generation. The knowledge and awareness about the prevalence of vertical maxillary excess will give an idea on where more focus must be implicated during diagnosis and lead to better treatment planning and more extraoral aesthetic outcome.

\section{Author Contribution}

Author 1(J.Chandrapooja) carried out the retrospective study by collecting data and drafted manuscripts performing the necessary statistical analysis. Author 2(Dr.Naveen Kumar) aided in the conception of the topic, participated in the study design, statistical analysis and coordinated in developing the manuscript 3(Dr. Ganesh Jeevanandhan) aided in coordinating and developing the manuscript. All the authors have equally contributed in developing the manuscript.

\section{Acknowledgement}

The authors would like to acknowledge the support of the depart- 
ment of Orthodontics and information technology of saveetha dental college and Hospitals and the management for their constant assistance with the research.

\section{References}

[1]. Lagerström LO, Nielsen IL, Lee R, Isaacson RJ. Dental and skeletal contributions to occlusal correction in patients treated with the high-pull headgear-activator combination. Am J Orthod Dentofacial Orthop. 1990 Jun;97(6):495-504.Pubmed PMID: 2353679

[2]. Vikram NR, Prabhakar R, Kumar SA, Karthikeyan MK, Saravanan R. Ball Headed Mini Implant. J Clin Diagn Res. 2017 Jan;11(1):ZL02-3.

[3]. Rubika J, Felicita AS, Sivambiga V. Gonial angle as an indicator for the prediction of growth pattern. World J Dent. 2015;6(3):161-3.

[4]. Felicita AS, Chandrasekar S, Shanthasundari KK. Determination of craniofacial relation among the subethnic Indian population: a modified approach - (Sagittal relation). Indian J Dent Res. 2012 May-Jun;23(3):305-12. Pubmed PMID: 23059564.

[5]. Angelillo JC, Dolan EA. The surgical correction of vertical maxillary excess (long face syndrome). Ann. Plast. Surg. 1982 Jan 1;8(1):64-70.

[6]. Bansal AK, Sharma M, Kumar P, Nehra K, Kumar S. Long face syndrome: A literature review. J. dent health oral disord. ther. 2015;2(6):00071.

[7]. Viswanath A, Ramamurthy J, Dinesh SP, Srinivas A. Obstructive sleep apnea: awakening the hidden truth. Niger J Clin Pract. 2015 Jan-Feb;18(1):1-7. PMID: 25511335

[8]. Bailey LJ, Haltiwanger LH, Blakey GH, Proffit WR. Who seeks surgicalorthodontic treatment: a current review. Int J Adult Orthodon Orthognath Surg. 2001 Winter;16(4):280-92.Pubmed PMID: 12390006.

[9]. Dinesh SP, Arun AV, Sundari KK, Samantha C, Ambika K. An indigenously designed apparatus for measuring orthodontic force. J Clin Diagn Res. 2013 Nov;7(11):2623-6.Pubmed PMID: 24392423

[10]. Felicita AS. Orthodontic extrusion of Ellis Class VIII fracture of maxillary lateral incisor - The sling shot method. Saudi Dent J. 2018 Jul;30(3):265269.Pubmed PMID: 29942113.

[11]. Cardoso Mde A, Castro RC, Li An T, Normando D, Garib DG, Capelozza Filho L. Prevalence of long face pattern in Brazilian individuals of different ethnic backgrounds. J Appl Oral Sci. 2013 Mar-Apr;21(2):150-6.Pubmed PMID: 23739865

[12]. Willems G, De Bruyne I, Verdonck A, Fieuws S, Carels C. Prevalence of dentofacial characteristics in a belgian orthodontic population. Clin Oral Investig. 2001 Dec;5(4):220-6.Pubmed PMID: 11800434

[13]. Samantha C, Sundari S, Chandrasekhar S, Sivamurty G, Dinesh S. Comparative evaluation of two Bis-GMA based orthodontic bonding adhesives-A randomized clinical trial. J Clin Diagn Res. 2017 Apr;11(4):ZC40-4.

[14]. Krishnan S, Pandian S, Kumar S A. Effect of bisphosphonates on orthodontic tooth movement-an update. J Clin Diagn Res. 2015 Apr;9(4):ZE01-5. Pubmed PMID: 26023659

[15]. Kamisetty SK, Verma JK, Arun, Sundari S, Chandrasekhar S, Kumar A. SBS vs Inhouse Recycling Methods-An Invitro Evaluation. J Clin Diagn Res. 2015 Sep;9(9):ZC04-8.Pubmed PMID: 26501002.

[16]. Ramesh Kumar KR, Shanta Sundari KK, Venkatesan A, Chandrasekar S. Depth of resin penetration into enamel with 3 types of enamel conditioning methods: a confocal microscopic study. Am J Orthod Dentofacial Orthop. 2011 Oct;140(4):479-85.Pubmed PMID: 21967934.

[17]. Felicita AS. Orthodontic management of a dilacerated central incisor and partially impacted canine with unilateral extraction - A case report. Saudi Dent J. 2017 Oct;29(4):185-193.Pubmed PMID: 29033530

[18]. Alteneiji M, Liaw JJ, Vaid NR, Ferguson DJ, Makki L. Treatment of VME using extra-alveolar TADs: Quantification of treatment effects. Semin Orthod. 2018 Mar 1;24(1):123-34.

[19]. Sivamurthy G, Sundari S. Stress distribution patterns at mini-implant site during retraction and intrusion--a three-dimensional finite element study. Prog Orthod. 2016;17:4.Pubmed PMID: 26780464.

[20]. Felicita AS. Quantification of intrusive/retraction force and moment generated during en-masse retraction of maxillary anterior teeth using mini-implants: A conceptual approach. Dental Press J Orthod. 2017 SepOct;22(5):47-55.Pubmed PMID: 29160344.

[21]. Jain RK, Kumar SP, Manjula WS. Comparison of intrusion effects on maxillary incisors among mini implant anchorage, j-hook headgear and utility arch. J Clin Diagn Res. 2014 Jul;8(7):ZC21-4.Pubmed PMID: 25177631.

[22]. Hafeez N. Accessory foramen in the middle cranial fossa. Res J Pharm Technol. 2016;9(11):1880-2.

[23]. Krishnan RP, Ramani P, Sherlin HJ, Sukumaran G, Ramasubramanian A, Jayaraj G, et al. Surgical Specimen Handover from Operation Theater to Laboratory: A Survey. Ann Maxillofac Surg. 2018 Jul-Dec;8(2):234-238.

\section{Pubmed PMID: 30693238.}

[24]. Somasundaram S, Ravi K, Rajapandian K, Gurunathan D. Fluoride Content of Bottled Drinking Water in Chennai, Tamilnadu. J Clin Diagn Res. 2015 Oct;9(10):ZC32-4.Pubmed PMID: 26557612.

[25]. Kumar S, Rahman R. Knowledge, awareness, and practices regarding biomedical waste management among undergraduate dental students. Asian J Pharm Clin Res. 2017 Aug 1;10(8):341

[26]. Gurunathan D, Shanmugaavel AK. Dental neglect among children in Chennai. J Indian Soc Pedod Prev Dent. 2016 Oct 1;34(4):364.

[27]. Sneha S. Knowledge and awareness regarding antibiotic prophylaxis for infective endocarditis among undergraduate dental students. Asian J Pharm Clin Res. 2016 Oct 1:154-9.

[28]. Dhinesh B, Lalvani JI, Parthasarathy M, Annamalai K. An assessment on performance, emission and combustion characteristics of single cylinder diesel engine powered by Cymbopogon flexuosus biofuel. Energy Convers Manage. 2016 Jun 1;117:466-74.

[29]. Choudhari S, Thenmozhi MS. Occurrence and Importance of Posterior Condylar Foramen. Res. J. Pharm. Technol. 2016;8:11-43.

[30]. Paramasivam A, Vijayashree Priyadharsini J, Raghunandhakumar S. N6adenosine methylation (m6A): a promising new molecular target in hypertension and cardiovascular diseases. Hypertens Res. 2020 Feb;43(2):153154.Pubmed PMID: 31578458.

[31]. Wu F, Zhu J, Li G, Wang J, Veeraraghavan VP, Krishna Mohan S, et al. Biologically synthesized green gold nanoparticles from Siberian ginseng induce growth-inhibitory effect on melanoma cells (B16). Artif Cells Nanomed Biotechnol. 2019 Dec;47(1):3297-3305.Pubmed PMID: 31379212.

[32]. Palati S, Ramani P, Shrelin HJ, Sukumaran G, Ramasubramanian A, Don $\mathrm{KR}$, et al. Knowledge, Attitude and practice survey on the perspective of oral lesions and dental health in geriatric patients residing in old age homes. Indian J Dent Res. 2020 Jan-Feb;31(1):22-25.Pubmed PMID: 32246676.

[33]. Saravanan M, Arokiyaraj S, Lakshmi T, Pugazhendhi A. Synthesis of silver nanoparticles from Phenerochaete chrysosporium (MTCC-787) and their antibacterial activity against human pathogenic bacteria. Microb Pathog. 2018 Apr;117:68-72.Pubmed PMID: 29427709.

[34]. Govindaraju L, Gurunathan D. Effectiveness of Chewable Tooth Brush in Children-A Prospective Clinical Study. J Clin Diagn Res. 2017 Mar;11(3):ZC31-ZC34.Pubmed PMID: 28511505.

[35]. Vijayakumar Jain S, Muthusekhar MR, Baig MF, Senthilnathan P, Loganathan S, Abdul Wahab PU, et al. Evaluation of Three-Dimensional Changes in Pharyngeal Airway Following Isolated Lefort One Osteotomy for the Correction of Vertical Maxillary Excess: A Prospective Study. J Maxillofac Oral Surg. 2019 Mar;18(1):139-146.Pubmed PMID: 30728705.

[36]. Tjan AH, Miller GD, The JG. Some esthetic factors in a smile. J Prosthet Dent. 1984 Jan;51(1):24-8.Pubmed PMID: 6583388.

[37]. Vijayashree Priyadharsini J. In silico validation of the non-antibiotic drugs acetaminophen and ibuprofen as antibacterial agents against red complex pathogens. J Periodontol. 2019 Dec;90(12):1441-1448.Pubmed PMID: 31257588.

[38]. Pc J, Marimuthu T, Devadoss P, Kumar SM. Prevalence and measurement of anterior loop of the mandibular canal using CBCT: A cross sectional study. Clin Implant Dent Relat Res. 2018 Apr 6;20(4):531-4.

[39]. Ramesh A, Varghese S, Jayakumar ND, Malaiappan S. Comparative estimation of sulfiredoxin levels between chronic periodontitis and healthy patients - A case-control study. J Periodontol. 2018 Oct;89(10):1241-1248.Pubmed PMID: 30044495.

[40]. Ramadurai N, Gurunathan D, Samuel AV, Subramanian E, Rodrigues SJ. Effectiveness of $2 \%$ Articaine as an anesthetic agent in children: randomized controlled trial. Clin Oral Investig. 2019 Sep;23(9):3543-50.

[41]. Sridharan G, Ramani P, Patankar S, Vijayaraghavan R. Evaluation of salivary metabolomics in oral leukoplakia and oral squamous cell carcinoma. J Oral Pathol Med. 2019 Apr;48(4):299-306.

[42]. Ezhilarasan D, Apoorva VS, Ashok Vardhan N. Syzygium cumini extract induced reactive oxygen species-mediated apoptosis in human oral squamous carcinoma cells. J Oral Pathol Med. 2019 Feb;48(2):115-121.Pubmed PMID: 30451321

[43]. Mathew MG, Samuel SR, Soni AJ, Roopa KB. Evaluation of adhesion of Streptococcus mutans, plaque accumulation on zirconia and stainless steel crowns, and surrounding gingival inflammation in primary molars: Randomized controlled trial. Clin Oral Investig. 2020;1-6. Mathew MG, Samuel SR, Soni AJ, Roopa KB. Evaluation of adhesion of Streptococcus mutans, plaque accumulation on zirconia and stainless steel crowns, and surrounding gingival inflammation in primary molars: randomized controlled trial. Clin Oral Investig. 2020 Sep;24(9):1-6.Pubmed PMID: 31955271.

[44]. Samuel SR. Can 5-year-olds sensibly self-report the impact of developmental enamel defects on their quality of life? Int J Paediatr Dent. 2021 Mar;31(2):285-286.Pubmed PMID: 32416620.

[45]. R H, Ramani P, Ramanathan A, R JM, S G, Ramasubramanian A, et al. 
CYP2 C9 polymorphism among patients with oral squamous cell carcinoma and its role in altering the metabolism of benzo[a]pyrene. Oral Surg Oral Med Oral Pathol Oral Radiol. 2020 Sep;130(3):306-312.Pubmed PMID: 32773350.

[46]. Chandrasekar R, Chandrasekhar S, Sundari KKS, Ravi P. Development and validation of a formula for objective assessment of cervical vertebral bone age. Prog Orthod. 2020 Oct 12;21(1):38.Pubmed PMID: 33043408.

[47]. Vijayashree Priyadharsini J, Smiline Girija AS, Paramasivam A. In silico analysis of virulence genes in an emerging dental pathogen A. baumannii and related species. Arch Oral Biol. 2018 Oct;94:93-98.Pubmed PMID: 30015217. 